\title{
"My parents, they became poor": The Socio-Economic Effects of the Expropriation and Relocation of Stoney Point Reserve \#43, 1942
}

\section{Helen Roos}

ABSTRACT: On 14 April 1942 the Stoney Point Reserve was expropriated by the Department of National Defence and Indian Affairs. The land was required for an advanced military training camp to support the war efiort. The Stoney Point families were quickly relocated to the neighbouring Kettle Point Reserve \#44. The loss of the reserve was a traumatic experience for the small Stoney Point band and resulted in severe economic and social problems. Physical removal caused widespread poverty among the band due to inadequate compensation, separation from resources and work, and a reliance on welfare. Socially, the Stoney Pointers suffered from an identity crisis, feeling disjointed from their community and its roots. This case study provides an examination of the effects of expropriation and relocation on Native communities.

On 17 April 1942, the Department of National Defence expropriated the Stoney Point Reserve for use as a military training camp. Indian Affairs coordinated the relocation of the Stoney Point community, a group of approximately 100 people, ${ }^{1}$ five kilometres west to the Kettle Point Reserve. The expropriation of a Native reserve for the war effort did not cause an outpouring of resistance among Canadians. However, to the Stoney Point families, the incident was no minor matter. The loss of the land caused significant social and economic dissuption within the community.

While fifty years had passed, neither the military or Indian Affairs made much initiative to return the land. However, in the early 1990s the survivors of the relocation began raising legal and media awareness of the outstanding Crown obligation. Little changed though, as the political machine failed 
to take the concerns of the band seriously and stalled all negotiations. The military continued to occupy the land until 1995. The shooting death of Dudley George by the Ontario Provincial Police made the land claim a national news item and pushed it to the political forefront.

There are no published works devoted to the expropriation of Stoney Point. Peter Schmalz briefly mentioned the event in The Ojibwa of Southern Ontario, directing readers simply of the military's use of the War Measures Act to acquire the land. ${ }^{2} \mathrm{He}$ failed to examine the bureaucratic process and effects of relocation on the band. On the other hand, Victor Gulewitsch, a Kettle \& Stony Point employee, provided rather biased accounts in a few unpublished booklets. ${ }^{3}$ The Royal Commission on Aboriginal Peoples' final report Looking Fonward, Looking Back serves as the only published comment, albeit scant, on the event. ${ }^{4}$ The report stated:

Many other bands were pressured into long-term leases or outright sale, but the residents of Kettle and Stoney Point had to submit to expropriation, and the provisions to negotiate for a return of their land-which was presumably needed for "efficient prosecution of the war"-were not acted upon after the war. The government invested great energy in acquiring such land, but it ignored or minimized its obligations after the war. Perhaps the government never understood the profound importance of land to Canada's Aboriginal people and what recognition of their service would have meant to them. ${ }^{s}$

The commission concluded that dispossession of the reserve and relocation to Kettle Point negatively affected the band on social, economicand political levels. However, the report failed to provide any documentary evidence to support its claim, relying solely on oral testimony from relocated band members and their descendants. 
The commission dedicated an entire chapter of discussion on the social and economic effects of relocation. The phenomenon, called culture stress, is also termed social disarticulation, social geometry, and ethnocide in the international body of literature. ${ }^{6}$ The effects of forced relocation included the loss of land base, economic decline, deteriorating health, and sociopolitical change. ${ }^{7}$ The report concluded that economic and sociopolitical deterioration was inevitable among the many Native communities that underwent massive, imposed and uncontrollable change.

The effects of relocation expressed by the Stoney Point band members were consistent with other indigenous removals worldwide. The study of relocation in Canada is relatively disjointed, with the Royal Commission report marking the first real effort to consolidate the availableinformation. Canadian scholars have failed to discuss the theoretical aspects of land management and relocation, which other scholars have. Canadian cases are largely descriptive examples of post-war relocations, and have yet to examine the broader development of colonial policies toward dispossession and the practice of relocation in Canada. ${ }^{8}$ An exception is Schmalz's History of the Saugeen Indians which recognized a colonial tradition of expropriation and relocation.9 The royal commission's final report raised awareness of this important, but largely neglected, field of study in Canada. ${ }^{10}$ However, are the commission's conclusions about Stoney Point-based on general comparisons with experiences of other bands, and with no examination of the documentary evidence-accurate?

After a review of both sources, this paper suggests that the documentary and oral evidence concur with the commission's conclusion that expropriation and relocation placed significant stress on the band. The socio-economic hardship was largely due to this event, but was also brought about by broader pressures for public land, wartime emotion, longstanding bureaucratic mismanagement of Stoney Point affairs, and intra-band conflict. A review of the entire event 
through documentary sources, maps, fieldwork and oral interviews revealed multiple causes of the band's situation. This paper will limit discussion to the importance of land to the Stoney Point band, and show why dispossession and removal from the hereditary land caused social and economic hardship.

The expropriation and relocation of Stoney Point Reserve \#43 occurred during a critical juncture in the Second World War. The bombing of Pearl Harbor on 7 December 1941, and the debilitating defeat in Hong Kong on Christmas Day of the same year motivated Canada into a whirlwind of action. The losses in battle spurred the public to criticize the Department of National Defence for insufficiently training Canadian soldiers." In response, Defence Minister James Layton Ralston authorized the construction of six new basictraining camps and two advanced training centres, bringing the total training facilities to thirty-four basic and twenty-three advanced centres. ${ }^{12}$ The expansion delivered a 40-per cent increase in training capacity. ${ }^{13}$

In the flurry of expansion, Brigadier General D. J. MacDonald of Military District No. 1 drew on local Southern Ontario support for a total war effort. Brig.-Gen. MacDonald expected recruitment to be the greatest since the beginning of the war. This was attributed to the mobilization of the Canadian Fusiliers and the calling up of more people to the "tide of the war." 4 In response, MacDonald worked quickly to establish an advanced training camp at a suitable location in Southem Ontario. Finding the Stoney Point Reserve \#43 suitable for his purpose, he went to work to acquire the land.

MacDonald considered the reserve an excellent location for an advanced training centre. The reserve was ideal because the site, located on the shore of Lake Huron and in the western part of the district, would draw from the basic training centres in London, Chatham, and Listowel. The location would also draw additional recruits from Windsor, Sarnia, and the local 
farms where enlistment was low. Moreover, the contour of the land, being largely forested, sandy and spotted with inland lakes, was ideal for barracks, manoeuvering grounds and rifle ranges. ${ }^{15}$ Hence, between February and March of 1942, MacDonald's officers worked with Indian Affairs to acquire the reserve.

Indian Affairs fully supported the Department of National Defence's proposal. The Reserve would contribute to the broader public interest of defence and the total war effort. The war provided a convenient opportunity to justify offloading the reserve. For over 30 years, Indian Affairs tried to seek a surrender to local residents and municipal governments for cottages and tourist industries. In 1928, the Indian Agent was successful in coercing a surrender 300 acres of beachfront for private cottages through bribes and payoffs, while in 1936, the Province of Ontario forced a purchase of land to establish a provincial park. After 40 years of effectively entrenching the notion that Stoney Point Reserve \#43 would never achieve agricultural self-sufficiency, Indian Affairs did little to safeguard the band's interest in the reserve. Hence, in support of the war effort, and as an attempt to relieve the administrative burden, Indian Affairs supported the military's plan.

The band vehemently resisted the surrender proposal for several reasons. First, the community considered the reserve an important to safeguard for future generations. ${ }^{16}$ Out of two million acres originally ceded to the Crown in 1829 , the band retained only 2,240 acres after a century of white encroachment. ${ }^{17}$ Second, band members raised their concern that over 4,000 acres of non-Native land was available through the Canada Company five kilometres east on Highway 21 . While Indian Affairs did not research this claim, records indicate that the military was certainly aware of the land. Perhaps the military was unwilling to pay the market value for the land, or spend valuable time building roads and bridges. Nevertheless, the issue of the Canada Company land was ignored. Third, some members opposed the purchase proposal 
arguing that the price of $\$ 50,000$ was well under market value and insufficient to justify a surrender.

On 1 April 1942, after a lengthy question and discussion period of three hours, the male members of the band voted on the proposal. It was the first time that the band council heard the details of the proposal. Voting members were angry that they were given no opportunity to participate in negotiations regarding their land. The decision was 13 in favour, 59 against the sale; the Stoney Point band rejected the proposal. Disappointed and angry, MacDonald appropriated the reserve with the War Measures Act on 17 April 1942. Between the months of May and June, Indian Affairs arranged for the removal of the band to nearby Kettle Point Reserve \#44. Senior officials worked to verify individual compensation entitlements, while the local Indian agent, William MoCracken, coordinated the physical removal of the band. However, Indian Affairs did little to protect the band's interests in safeguarding possession of the land.

Well before the expropriation, Indian Affairs held a notion that the Stoney Point band was part of the larger Kettle Point band. Indian Agent George Down stated, "personally I think this is a wonderful opportunity to gather a few straggling Indians and locate them permanently with the main body of the Band at Kettle Point."18 The bands conjoined in 1920 as a single council in order to amass strength in numbers on political decisions concerning the small reserves. The families intermarried between the two communities for several generations.

However, there were certain social and economic distinctions that maintained the distinctiveness of Stoney Point as a unique and separate community from Kettle Point. Stoney Point was designated Reserve \#43, while Kettle Point was numbered 44. ${ }^{19}$ Administratively, Indian Affairs registered and affiliated band members according to their reserve. Treaty annuities were paid and noted according to membership on a particular reserve. The notion that the bands were simply 
extensions of a larger band at Kettle Point was fallacious on an administrative level, and certainly not true based on a sense of identity among the bands. Each community was distinct in social identity, economic pursuits and bureaucratic administration.

The importance of the reserve as a land base to the Stoney Point community was profound. The land surrounding the tip of the "stony point" of Lake Huron was the community's traditional land since time immemorial. The land was spotted with graves of ancestors, provided the resources for sustenance, and cradled the spirit of the community. In "Performing Native Identities through English Discourse," Lisa Valentine argues that among the Ojibwa peoples, identity is intrinsically associated with the land. ${ }^{20}$ She claims that unlike other Native groups, "the concept of Nation is framed in terms of a land base, in terms of traditional regional or areal affiliations, and in terms of land usage."21 The designation as a "Stoney Pointer" for example, is more important than being called Ojibwa or Chippewa, which are linguistic classifications. Identity among southwestern Ontario Ojibwa people, whether from the Sarnia, Kettle Point or Stoney Point reserves is linked largely to the economic, social and spiritual connections that stem from the land.

In the case of the Stoney Point band, their sense of personal and community identity was extinguished largely from dispossession of the reserve, and physical separation from the land. Individuals were stripped of these connections to the land, which provided a sense of personal identity and their livelihood. On a broader level, the land connected the community to a sense of continuity with the past and with a traditional homeland. Indian Affairs officials failed to consider the subtleties of a cultural connection or sense of identity as it existed among the bands.

The expropriation and relocation were not the sole causes of the trauma. A longstanding direction in Indian Affairs administration and management of Stoney Point showed little 
concern over a Native "connection" to land. The Indian Agents responsible for Stoney Point considered conjoining the Kettle Point and Stoney Point communities for over 40 years. ${ }^{2}$ By surrendering the Stoney Point Reserve, Indian Affairs would save money in administrative costs. Agent Down declared that relocation "would solve many problems and dispense with a great deal of expense from both Band Funds and Departmental Appropriations such as schools, roads, visitations, etc.... [which] is maintained to accommodate twelve families."23

Expropriation and relocation also served another economic agenda. The Stoney Point band showed little promise of largescale agricultural development. Farming was the aim for most reserves in Ontario during the early decades of the twentieth century. Unfortunately, the Stoney Point band was not interested in devoting full-time efforts to clearing land or becoming self-sufficient farmers. Hence, Indian Affairs supported surrender proposals that advocated what they considered to bea "productive use" of the land. The lakefront reserve had potential for development with cottages, tourist industries and parkland, which would serve the larger public interest. Indian Affairs hoped to relieve the Stoney Point band of the "burden" of ownership or title to the land.

In conversations with surviving band members, the issue of identity was important, both on a personal level and within the context of community. Pearl George, a 20-year old bride at the time of the event recalled her life on Stoney Point. As a young girl, Pearl grew up with her grandparents and the three survived solely from the fruits of their labours on the land. The daily routine for many women involved collecting berries and fruits such as thimbleberries, raspberries and strawberries. The women canned the fruit as jam or made into pies. ${ }^{24}$ Women also harvested the vegetables from their small garden plots, pickling and canning the food to provide winter supplies. Subsistence farming was the main source of food for the entire Stoney Point community. Families cleared small parcels of 
land, planted crops, and had a few laying hens for eggs and meat, which satisfied their daily needs. Indian Affairs worked to infuse an idea that large-scale cash crop production was the only method of achieving self-sufficiency, but the band chose to maintain its traditional routine of small garden plots.

Each family used the land for their own purposes. Individuals like Emest Bressette were considered full-time farmers and "successful" by the Indian Agent since he practiced extensive farming with cash crops. Other families who did not clear their land rented portions as pastures for additional money. As Pearl explained, "it was the only way we could survive."2s Clifford George, a Stoney Point veteran of the Second World War, also remembered the community as living "hand to mouth." George stated: "[We] utilized everything around us. We didn't starve, but we were hungry a lot of times." ${ }^{.25}$ Although the small-scale farming of the land was far from self-sufficient, the surviving locatees hold a generally positive impression of the community in the 1940s. George summarized the culture of the community by saying "everybody pulled together and helped each other out, just as the [local white] farmers helped each other out."27 In his mind, the Stoney Point community was no better or worse off than other local families.

Families needed to supplement their small-scale farming with work in other areas for money. The band worked in a wide variety of jobs off-reserve. ${ }^{28}$ Men and women hired themselves out to local farmers to work in the celery fields, while young ladies worked as domestics in local communities. ${ }^{29}$ The men often worked in the Forest Basket Factory that supplied farmers with bushel baskets, or on the Grand Trunk Railway doing heavy labour. However, removal to Kettle Point stopped participation for many in these areas of employment. Without transportation, people could not travel the additional eight kilometres on foot to work. Many Stoney Pointers had no choice but to leave Kettle Point to find work in Detroit, 
Hamilton and Port Huron. The distance between work and home fractured the community. ${ }^{30}$

Apart from farming, Stoney Pointers used other resources from the land to create saleable items. The women were wellknown throughout the region for their reed baskets, while men made chairs and tables from branches and twigs. Others produced items of detailed beadwork, or dreamcatchers, ${ }^{31}$ which fostered a large economic industry in the region. The summer season brought tourists and local residents to the sandy beaches of Stoney Point. The influx of people served as a convenient client base for the rustic crafts and garnered a reputation for excellent craftsmanship and quality. However, removal to Kettle Point curtailed the craft industry among the Stoney Pointers.

The Kettle Point Reserve was a fishing community as the physical features of the land were inconducive to farming. For the farmers of Stoney Point, removal to the swampland of the $14^{\text {th }}$ Concession stripped many families of the ability to maintain their livelihood. The esteemed black barrister, Bertrand Joseph Spencer Pitt, made an important statement to Indian Affairs in his defence of the Stoney Point band claiming that the land and timber was the "bread and butter" of the band. ${ }^{32}$ Without access to the timber, families could not heat their homes, or sell wood for cash. Without the ability to garden, families could not grow food for daily consumption, or grow crops for winter supplies of canned food. Without the branches from the trees, the summer craft industry also collapsed, while the extra money derived from renting land for pastures also ceased. In effect, the economic livelihood of the Stoney Point community was shattered. The summer industries of the Kettle Point people continued as fishing guides, but the Stoney Pointers had no access to resources to continue their trades.

Removal also severed the spiritual connection to the land. As an elderly band member recalled, the Indian Agent denied her permission to bring her prized rose bushes to Kettle 
Point ${ }^{3}$ This seemingly insignificant item distressed the woman, not because the bushes were valuable, but because she desperately wanted to maintain a physical connection to her home at Stoney Point. Pearl George confirmed this need to be attached to Stoney Point. In her experience, she felt little attachment to the baskets she made while living on Kettle Point. Born and raised on Stoney Point, George created her baskets from the grasses of her homeland. The grass at Kettle Point was not the same. The composition was coarser than that found on Stoney Point, and it held little spiritual attachment for her. She felt that only those materials found on Stoney Point that have a cultural and spiritual significance were appropriate to use in her baskets.

The attachment to land also contributed to the sense of belonging to a larger community. Rachel Shawkence, in the work"Annie Rachel: Mshkikiikwe-Stories from an Elder of the Kettle and Stony Point First Nation" reminisced about life on Stoney Point. Shawkence's words were tempered by a unique affiliation to both communities, bom and raised at Stoney Point, but married a Kettle Point man and settled on Kettle Point. She recalled fondly some memories of Stoney Point: "My grandmother used to say that my dad spirited my mother away with a love-potion, but the only love-potion he had was some maple sugar. Everybody liked his maple sugar." ${ }^{34}$ Crafts and products from the land were shared among the community. Individuals developed reputations from the quality of their wares and the specialization of their craft. Like Gilford Henry's maple sugar, William George had a considerable reputation among the community for his rustic furniture. ${ }^{35}$ Other people were renowned for their tools or implements derived from the wood found on Stoney Point.

The community also held a spiritual connection to the land due to the sacred places of burial grounds and stories of their ancestors. Separation from the cemetery, which contained the burials of hereditary chiefs and family members, was devastating to the community. Robert George was traumatized 
when he returned to Canada after fighting in the Second World War to find the reserve inhabited by the military. Once he was granted permission to visit the cemetery, he was emotionally distraught by the desecration of the sacred site.

Mr. George was greatly concerned about the state of the Indian cemetery at the former Stony Point Reserve When the Indians were moved [the] National Defence Department promised not to have any damage created to the Indian cemetery only two tombstones were remaining on the grounds and that these were marked with shell shots. I noted one red granite marker had two distinct marks of being hit a glancing shot by a high calibre rifle bullet. A second stone, white marble, was broken and a considerable distance displaced from its grave position. Mr. George pointed out that a great number other tombstones has been moved. ${ }^{36}$

George could not find his mother's grave, as there were no markers to indicate where it was. The desecration of the cemetery showed considerable disrespect by the military, and caused a profound sense of loss within the Stoney Point community.

Examples of insensitivity and disrespect toward the band were scattered throughout the documentary sources on the expropriation and relocation. The actions and decisions of Indian Affairs officials were instrumental in fostering interband conflict between the Kettle Point and Stoney Point communities. On a social level, the Indian Agent used a psychological method of name-calling, which encouraged conflict between the two communities. Agent William McCracken called the Stoney Point members "refugees," "immigrants" and "D.P's," or displaced persons, which hindered their ability to integrate effectively into the Kettle Point community. ${ }^{37}$ Since relocation required the use of additional land on Kettle Point, McCracken aroused the fear 
that little land would be available for Kettle Point children after the Stoney Point members settled. McCracken provoked fights between individuals and was heard bellowing "you don't belong here" to the Stoney Point members. ${ }^{38}$ McCracken even went so far as to enfranchise a number of individuals in order to reduce the number of Stoney Pointers settling on Kettle Point. ${ }^{39}$

Indian Affairs' management of the relocation was very poor. The senior officials were more concerned with accommodating the needs of the military than safeguarding the interests of their wards at Stoney Point. Superintendent D. J. Allan was largely responsible for the details of relocation.

The buildings sold to the Department of National Defence may be either moved away or demolished by the former owners. This will have to be done, however, with very definite promptness as the army will not wait on their convenience and any shack that is not removed promptly might conceivably have a match touched to it to get it out of the road. ${ }^{40}$

As his comments reveal, Indian Affairs rushed to ensure that the military met their timelines. Under these circumstances, the department paid little attendtion to the Stoney Point members' financial interests. The military's purchase of Stoney Point for $\$ 50,000$ had several administrative stipulations, which were vehemently resisted by the band. First, the expropriation stated that individuals would receive money for the value of their land and buildings, and provided money to cover the moving costs of their houses. Second, individuals would have to pay for any repairs to their houses after removal from their proceeds of sale. Third, families would have to arrange for land at Kettle Point and pay for the land from their proceeds. From an examination of the documents, it was evident that the rushed decisions made by Indian Affairs positioned the families for inevitable impoverishment. 
Of the purchase price of $\$ 50,000$, families only received money for any arable land they owned in addition to the value of any houses or buildings. ${ }^{41}$ The band was furious that they would receive \$15 per acre for arable land only. This rendered their wood lots or inland lakes worthless. Farmers such as Emest Bressette fared well from the provision yielding $\$ 1,200$ for his land and buildings. However, in stark contrast, the majority of families held Location Tickets for several acres of non-arable land.

A considerable disparity resulted on the issue of compensation. Most families received a few hundred dollars for their arable land and buildings, while others received thousands of dollars. To add to the inequity, the military paid $\$ 15$ per acre for the land at Stoney Point, but McCracken arranged for land sales on Kettle Point at $\$ 20$ to $\$ 30$ per acre. ${ }^{42}$ Due to the mismanagement of compensation and the proceeds of sale, the majority of locatees were drained of money and resources even before setting foot on Kettle Point.

A few notable individuals refused to cooperate with Indian Affairs. Unfortunately these people found themselves in a drastic state. Moses George tried to stave off removal, but was unsuccessful. "The army started shootin' around his place, makin' big holes in the ground. Finally they had to movethey were forced."43 Elizabeth MacKinnon was determined to remain at Stoney Point, planting herself on her porch "a shotgun resting on her lap." ${ }^{\text {"44 }}$ McCracken had her forcibly removed by bailiffs.

As individuals delayed in finding land at Kettle Point or making arrangements to move their houses, McCracken took relocation into his own hands. Indian Affairs identified over ninety acres at Kettle Point that could be sold to Stoney Pointers. Otherwise, the only other land available was the swampland of the $14^{\text {th }}$ Concession. Henry and Pearl George made arrangements for their house to be moved to suitable land. However, without their knowledge, their house was hoisted and prepared for moving. 
It happened as if overnight. Without warning, we were working in the local farms only to find one evening, our home on steel or wood beams, prepared for moving. I had no for-knowledge we were to be moved, otherwise, I would have prepared to pack. Everything we owned was trashed. Every cup, plate and bowl we used was smashed. The only belongings left were the cloth[e]s we owned and the damaged house. ${ }^{45}$

The Georges found their home in a state of considerable disrepair two days later in the swamp.

The old houses simply could not withstand the move to Kettle Point. One family was forced to live without a kitchen, as theirs was left at Stoney Point. ${ }^{46}$ A common image was of the houses propped up on Oliver Tremaine's flat-bed truck, with shingles torn off and a dismantled chimney left on the ground. Every home required repair after moving, but many families simply had no extra money from their proceeds of sale. For those that had money, McCracken provided prepaid coupons for materials from a local store.

Not all houses could be salvaged. Some homes and log cabins were too fragile to move. In these cases, Oliver Tremaine demolished the dwellings and the people received money for the salvaged material. McCracken tried to find abandoned farmhouses in the district for these people. Moses George purchased such a house for $\$ 200$. Gladys Lunham recalled vividly the house after it was moved. She claimed Tremaine left it standing on "great big old logs and the floor left rough."47 Lunham declared: "The house wasn't even livable. Rats ran through it and it was not winterized. There was no insulation or nothing. ${ }^{249}$ Housing officials declared the house condemned three years after relocating to Kettle Point. George simply could not afford to make the extensive repairs required to keep the house habitable. He moved his family off Kettle Point to nearby Thedford, Ontario. 
For families living in the swamp, there were other problems. It was difficult for farming-folk to sustain gardens on the swampland. The land was sand and water, and the area had poor drainage. The swamp had no fresh water and Indian Affairs did not provide access to potable sources of water. As Rachel Shawkence noted:

I was goin' through something last night, I don't know what it was. Maybe something to do with that polluted water back here. They're diggin' that ol' stump out, an' they made quite a hole around it; that just filled right up with black, awful-lookin' water. I think I'm gonna burn something an' put it in there so it don't makeus sick. ${ }^{49}$

Henry and Pearl George attribute the black water to the death of three children.

I lost twin girls after the move, and I had those children at home. I think what happened was that water out there. There was no running water. The water was contaminated. I didn't feel too good drinking that swamp water. Ihad the doctor come in because my stomach did not feel goodI think that's that water. And then I had a little boy too, 2 years old. The conditions of the water did not agree with the children nor me. ${ }^{\text {so }}$

The mortality rate among Stoney Pointers is an important question for further study. However, it serves to illustrate that the drastic results of relocation were not always due to money. In its haste, Indian Affairs failed to consider the health and economic implications of removal to the swampland and their decision had drastic consequences. Gladys Lunham summarized the experience of the majority of Stoney Pointers when she claimed: 
My parents, they became poor. They were poorer than when they were down there [on Stoney Point], because they had a garden there and they owned a house. They never had to go out to work, or live on welfare. They made crafts-Indian crafts. But when they got down here my mother had to leave the younger children and go out to work. My dad had to go a long ways to get wood. We were poor after that. So I don't think it was really fair to force a family out of their home like that. ${ }^{\text {s1 }}$

It is indisputable that the Stoney Point community, either socially or economically, suffered from the expropriation of the Reserve and relocation to Kettle Point in 1942.

The elders argued that "the move introduced 'Relief" or welfare to the band" and claimed that welfare toppled the community's already weakened traditional economy. ${ }^{52}$ Naturally the band considered relocation to Kettle Point as the major cause for the disintegration of the community. Inadequate compensation for the land and buildings, coupled with relocation to unproductive land and limited work opportunities, forced many families into poverty. However, relocation as a sole cause of the community's deterioration is insufficient. A few families certainly profited from the sale of their land on Stoney Point, and prospered in their new homes at Kettle Point.

A longstanding history of bureaucratic pressure also influenced the event. For over 30 years Indian Affairs had worked to surrender portions of Stoney Point for private development and public projects. The influence of the local Indian Agent in the daily affairs and community relations was also instrumental. Inflaming tensions among the two communities made relocation and integration difficult. Hence, Stoney Point received little protection from Indian Affairs when the needs of war prevailed. 
Each family has their own story to tell. This work provides a glimpse into some of those experiences and misfortunes. The expropriation and relocation of Stoney Point was no anomaly in the history of Native-White relations. As the royal commission declared, the profound importance of land to Native people cannot be overemphasized. Native grievances over land and compensation will continue to proliferate. With further research we can make inroads into understanding the roots of Native dissent, and work to find means to redress the errors of the past.

NOTES

1 Clifford George, interview with author, 20 October 1996, Stoney Point, Ontario. This figure conflicts with the official documents, which estimate only 75 residents living on Stoney Point. There was also a tendency for people who worked off-reserve during the week to return to the reserve and live with family members in a small household. Kinship charts also support the argument of a larger population in 1942.

${ }^{2}$ Peter Schmalz, The Ojibwa of Southern Ontario (Toronto: University of Toronto press, 1991, 120-147.

' Victor Gulewitsch, "The Chippewas of Kettle \& Stony Point Camp Ipperwash" Unpublished booklet. (Kettle Point: Chippewas of Kettle \& Stony Point, 1997).

' Rene Duseault and George Erasmus, Report of the Royal Commission on Aboriginal Peoples: Looking Forward, Looking Back Vol. 1 (Queen's Printer, 1996).

'Ibid, 590.

'Theodore Downing "Mitigating Social Impoverishment when People are Involuntarily Displaced, "in Understanding Impoverishment, ed. Christopher McDowell (Providence: Berghahn Books, 1996), 34-41. See also E. Colson, The Social Consequences of Resettlement: The Impact of the Karibe Resettlement upon the Gwembe Tonga (Manchester: University of Zambia press by Manchester University Press, 1971); Art Hansen and Anthony Oliver-Smith, eds. Involuntary Migration and Resettlement (Boulder: Westview Press, 1988); and Michael Cernea and Scott Guggenheim, eds. Anthropological Approaches to Resettlement (Oxford: Westview Press, 1993).

' Duseault and Erasmus, Report of the Royal Commission on Aboriginal Peoples, 490. 
- Most works are largely descriptive studies of individual cases including Frank Tester and Peter Kulchyski, Tammarnitt (Mistakes): Inuit Relocation in the Eastern Arctic, 1939-1963 (Vancouver: UBC Press, 1994); Anastasia Shkilnyk, A Poison Stronger than Love: The Destruction of an Ojibwa Community, (New Haven: Yale University Press, 1985); Geoffrey York, The Dispossessed: Life and Death in Native Canada (Toronto: Lester \& Orpen Dennys, 1989); and Alan Rudolph Marcus, Relocating Eden: The Image and Politics of Inuit Exile in the Canadian Arctic (Hanover, NH: Dartmouth College: University Press of New England, 1995).

${ }^{9}$ Peter Schmalz, History of the Saugeen Indians (Ottawa: Ontario Historical Society, 1977).

${ }^{10}$ Dusealt and Erasmus, Report of the Royal Commission on Aboriginal Peoples, 411-505.

11 "Colonel Ralston to Make Statement in Commons: Battle Strength," Globe and Mail, 21 January 1942, 1-2.

12 Privy Council Minutes, "War Cabinet Committee," 27 January 1942. National Archives of Canada (hereafter referred to as NAC), Record Group 2.

${ }^{13}$ Col. C.P. Stacey, Arms, Men and Governments (Ottawa: Queen's Printer, 1970), 44.

4 NAC 13888, Brig.-Gen. D.J. MacDonald, "Weekly General Intelligence Report for week ending February 20, 1942," File: War Diary of Military District No. 1.

is NAC 7754, George Down, Sarnia, to T.RL. MacInnes, Ottawa, 5 Febnuary 1942.

${ }^{16}$ Helen Roos, "It Happened as if Overnight: The Expropriation and Relocation of Stoney Point Reserve \#43, 1942" (unpublished MA thesis, University of Western Ontario, 1998).

${ }^{17}$ R.J. Surtees, Indian Land Surrenders in Ontario, 1763-1867 (Department of Indian Affairs and National Defence: Ottawa, 1984), 79.

${ }^{18}$ NAC7754, George Down to Superintendent T.R.L. MacInnes, Sarnia, Ontario, 5 February 1942.

19 J.L. Morris, Indians of Ontario (Toronto: Department of Lands and Forests, 1943), 73.

${ }^{20}$ Lisa Valentine, "Performing Native Identities Through English Discourse," Proceedings from the Twenty-Fifth Algonquian Conference (Ottawa: Carleton University, 1995), 3.

${ }^{21}$ Ibid.

nACRecord Group 10, V1. 7794, File 27029-2, PL 1 for details of the Crawford-Scott surrenders of 1928, WL. 2763, File 151,900 on surveying and subdivision of Stoney Point in 1900, and the House of Commons 
Sessional Debates from 1890 to 1930 for Indian Affairs' annual report for Stoney Point Reserve \#43.

2NAC 7754, Indian Agent George Down to Superintendent T.R.L. MacInnes, Samia, Ontario, 5 February 1942.

"Reta Pearl George, interview with author, 26 May 1997, Stoney Point, Ontario.

${ }^{25}$ Ibid.

${ }^{x}$ Clifford George, interview with Jan Trimble, July 1996, Stoney Point, Ontario.

"Ibid.

${ }^{29}$ Ibid.

${ }^{29}$ Reta Pearl George, interview with author, 26 May 1997, Stoney Point, Ontario.

${ }^{30}$ Lorraine George, Senior researcher on the Kettle \& Stony Point Oral History Project, interview with author, 11 August 1997, Kettle Point, Ontario.

"A dreamcatcher is a craft indigenous to the Ojibwa or Chippewa culture group. Within a circle, a web is created and affixed to the web are beads, jewels or other items. Hanging from the ring are eagle feathers of other materials. The dreamcatcher is hung in the bedroom so that evil spirits would be caught in the web and not cause bad dreams while asleep.

${ }^{32}$ NAC 7754, B.J. Spencer Pitt to W.L. MacKenzie King, May 1942, Toronto, Ontario.

${ }^{33}$ Lorraine George, interview with author, 11 August 1997.

H Bruce Milliken, "Spirit Food, Annie Rachel: Mishkikiikwo-Stories from an Elder of the Kettle and Stony Point First Nation," (unpublished booklet, Anthropology Department, University of Western Ontario), 39.

35 Clifford George, interview with Jan Trimble, July 1996, Stoney Point, Ontario.

${ }^{36}$ NAC File 471/36/-7-8, C.J. Connolly, Department of Health, to R.A. Hoey, National Defence, 30 October 1947, Winnipeg, Manitoba.

${ }^{3}$ NAC 7754, William McCracken to D.S. Allan, 15May 1942, Samia, Ontario.

${ }^{38}$ Lorraine George, interview with author, 11 August 1997.

${ }^{39}$ Ibid.

NAC 7754, D.J. Allan to William McCracken, 24 March 1942 Ottawa, Ontario.

"NAC 7754, "Appraisal of Improvement on Lots," June 1942. 42 Ibid.

${ }^{43}$ Bruce Milliken, "Holes in the Ground, Annie Rachel," 85. " "Pearl George," London Free Press, 15 August 1992, C3. 
${ }^{45}$ Pearl George, interview with author, 7 August 1997, Stoney Point, Ontario.

${ }^{46}$ Lorraine George, interview with author, 11 August 1997.

${ }^{47}$ Lambton County Archives, "Gladys Lunham of Kettle Point," n.d., Box 1, File 10A-AH "Kettle Point," 2.

${ }^{48}$ Ibid, 3.

"Bruce Milliken, "Black Water, Annie Rachel,"63.

${ }^{30}$ Pearl George, interview with author, 7 August 1997.

"1 Lambton County Archives, "Gladys Lunham of Kettle Point," 2. 32 "The Rebirth of a Nation," Forest Standard, 27 April 1988, 11. 